\title{
17. SEISMIC SEQUENCES OF CAPE BOJADOR, NORTHWEST AFRICA
}

\author{
K. Hinz, Bundesanstalt fur Geowissenschaften und Rohstoffe. Stilleweg 2, D-3000 Hannover 51, \\ Federal Republic of Germany
}

\begin{abstract}
In the seismic records off Cape Bojador, four main depositional sequences can be identified: (1) a pre-middle Aptian Lower Cretaceous sequence (CB3), represented by a divergent to subparallel reflection pattern; (2) an Aptian to Upper Cretaceous sequence (CB2), characterized by a divergent to subparallel pattern and a marked unconformity at the top; (3) a Cenozoic sequence (CB1a) restricted to the present shelf and upper slope off Cape Bojador; and (4) a Miocene to Quaternary sequence (CB1b) which was deposited on the lower slope and uppermost rise after erosion of large parts of the lower slope off Cape Bojador.

Regional accousto-stratigraphy should be based on seismic sequences, rather than on individual reflectors.
\end{abstract}

\section{INTRODUCTION}

Before drilling Site 397, two distinct unconformities $\left(D_{1}\right.$ and $\left.D_{2}\right)$, observed by single trace reflection seismic profiling underneath the continental slope of Cape Bojador (Hinz et al., 1974), were traced downslope from the shelf to the rise. By extrapolation of Spanish Sahara well data, these seismic horizons were stratigraphically classified as Oligocene/early Miocene $\left(D_{2}\right)$ and Cenomanian $\left(D_{1}\right)$ unconformities. The absence of upper Lower Cretaceous to Paleogene sediments at Site 397 , whose presence were predicted from conventionally interpreted seismic data, has shown that age-established seismic reflectors should not be traced downslope, before depositional sequences and their internal configuration have been defined and analyzed.

\section{DEPOSITIONAL SEQUENCES OFF CAPE BOJADOR}

Depositional sequences are commonly bounded by unconformities which often can be identified on the seismic records by the termination of systematic reflection patterns such as onlap, downlap, toplap, and erosional truncation (Vail and Mitchum, 1977).

We identified four main depositional sequences on the seismic records off Cape Bojador. The oldest sequence, CB3 (Figures 1 and 2), is characterized by a divergent to subparallel internal configuration on the upper part of this depositional sequence and by growth faults (Figure 2). A strong reflection below the slope (Figure 2) marks the surface of Sequence CB3. Beneath the lower slope and upper rise, by contrast the upper boundary of Sequence CB3 (stippled in Figures 1 and 2 ) is represented by proximal onlap against the pattern within Sequence CB3. These patterns terminate abruptly in a seaward direction, indicating a post-depositional erosional truncation of parts of Sequence CB3 below the present lower slope and rise. Below the present upper slope, the strong upper boundary of CB3 no longer exists. This might indicate a transition to a shelf facies. The available velocity data from Sequence CB3 increase with depth and range from 2.8 to $4 \mathrm{~km} /$ second.

Sequence CB2 is characterized by a subparallel to divergent internal pattern indicating seaward thinning of individual strata within this sequence. Sequence CB2 terminates seaward beneath the lower slope at a relatively steep interface with erosional truncation (stippled in Figures 1 and 2).

The upper boundary of Sequence CB2 is marked by a strong reflection horizon dipping gently downslope. This boundary separates the parallel to divergent pattern (e.g., thinning and pinching out of individual strata of Sequence CB2) from the downlapping Sequence CB1a (Figure 2, left side; Figure 1, right side). Therefore, this distinct unconformity, earlier dated as a Cenomanian unconformity (Hinz et al., 1974) and recently revised to Paleocene/Eocene (von Rad et al., in press), is interpreted as a nondepositional hiatus. The span of this hiatus appears to increase seaward. This unconformity cannot be correlated with the steep erosional surface and a strong reflector ( 3.5 to $4.7 \mathrm{sec}$ reflection time; Figure 2, right side) because the stratal terminations are different, e.g., downlap/toplap and/or concordant below the outer shelf and upper slope, and onlap/erosional trunction below the upper rise.

The velocity within Sequence CB2 increases with depth, and laterally in a landward direction, suggesting lateral and vertical facies changes within this depositional sequence.

Sequence $\mathrm{CB} 1 \mathrm{a}$, which locally is composed of thin differing units, downlaps against Sequence CB2 and terminates (in the case of Figure 1) against a hummocky to chaotic unit and (Figure 2) against a canyon. Therefore, it is not possible to unambiguously correlate units of Sequences CB1a and CB1b, which forms a complex set of depositional sequences. 


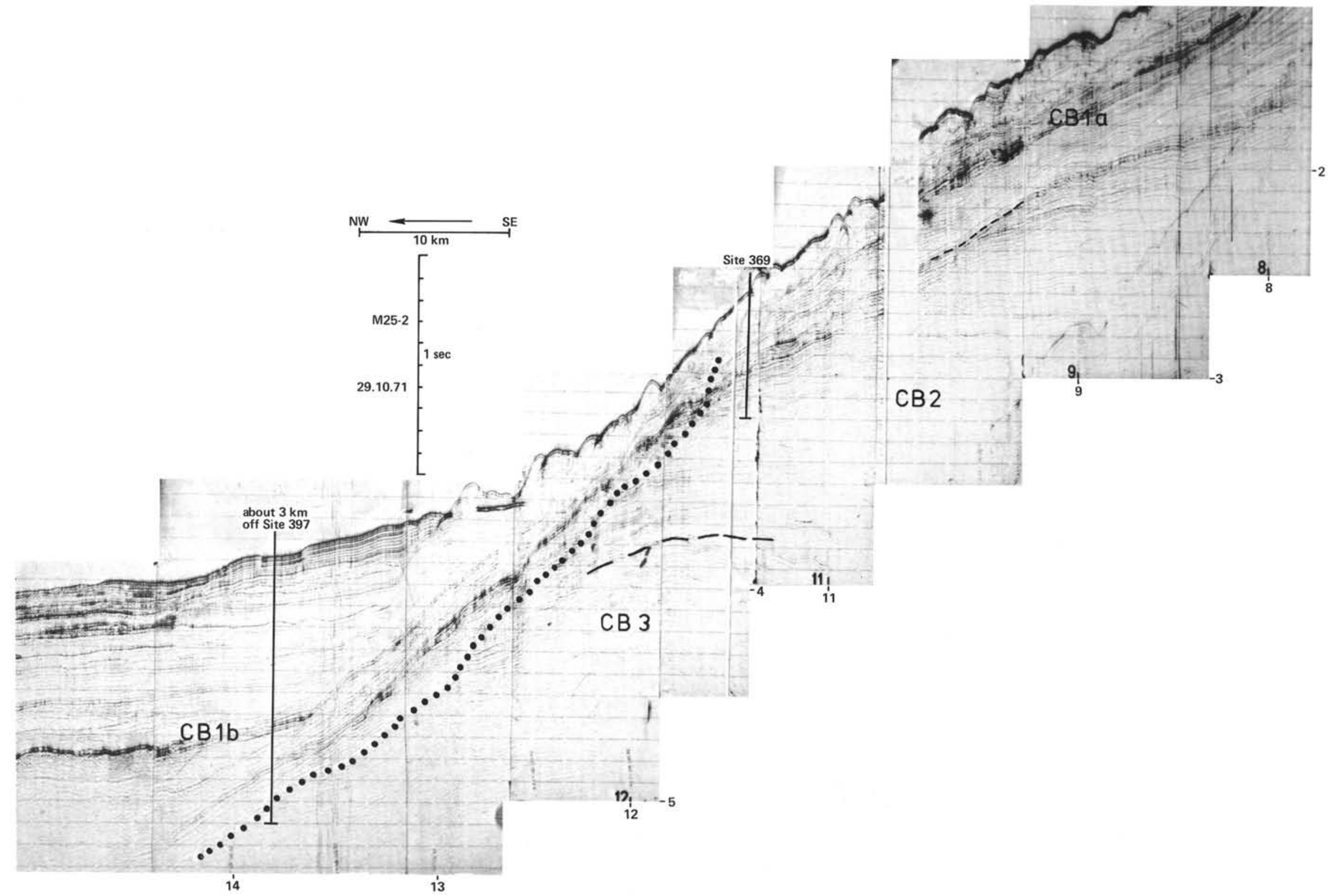

Figure 1. Seismic record off Cape Bojador in which the identifiable seismic sequences CB (Cape Bojador) 1a, 1b, 2, 3 are indicated. 


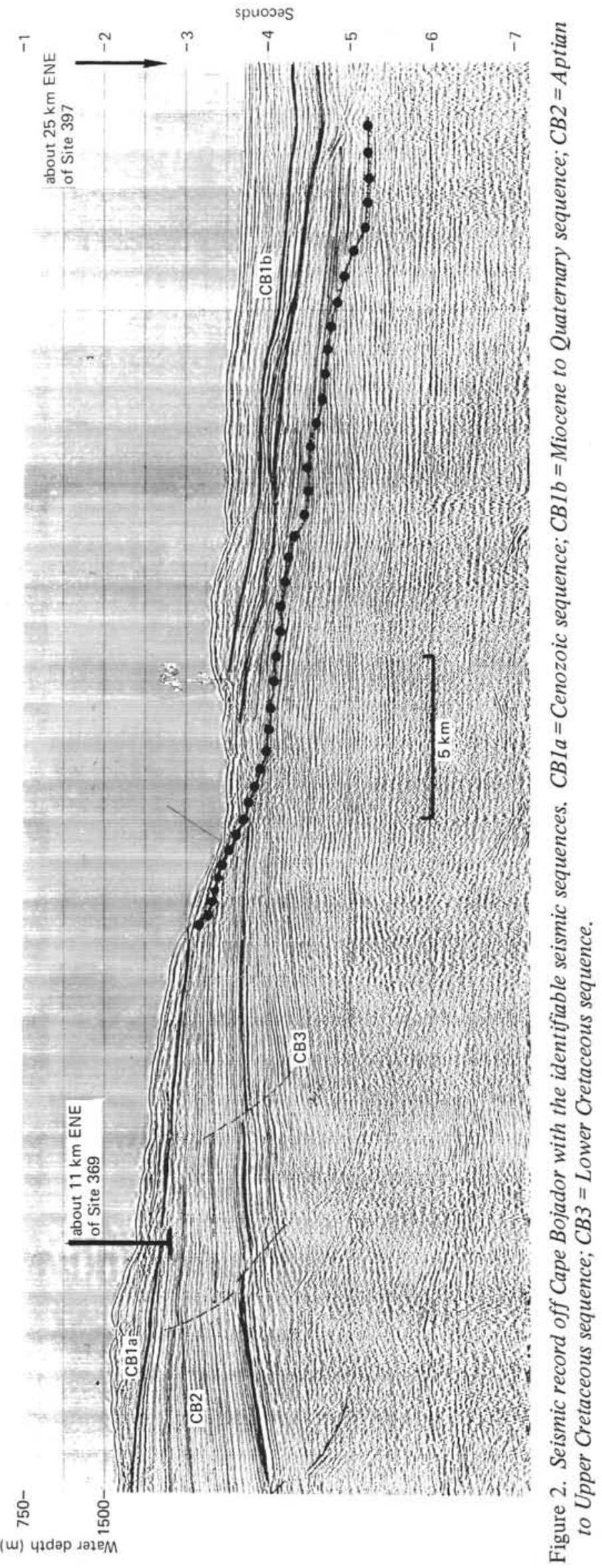

The seismic velocities within Sequences CBla vary from 1.7 to $2 \mathrm{~km} / \mathrm{second}$. Seismic velocities of 1.65 to $1.9 \mathrm{~km} / \mathrm{second}$ have been derived for the uppermost part with velocities of 2.0 to $2.6 \mathrm{~km} / \mathrm{second}$ for the lower part of Sequence CBIb.

\section{AGE AND INTERPRETATION OF SEISMIC SEQUENCES}

From Sequence CB3, 153 meters of Hauterivian, laminated, gray, silty mudstones were penetrated at Site 397. These sediments are interpreted as distal prodelta muds, rapidly deposited with rates of sedimentation between 75 to $150 \mathrm{~m} / \mathrm{m} . \mathrm{y}$. in water depths less than 1000 meters (Einsele and von Rad this volume). Assuming a sedimentation rate of $100 \mathrm{~m} / \mathrm{m} . \mathrm{y}$., the reflector which marks the upper boundary Sequence CB3 can be roughly dated as Barremian to Aptian.

The scientific results of Site 397 suggest that Sequence CB3 consists of Lower Cretaceous prodelta sediments originally deposited in less than 1000 meters water depth.

The recent total depth of the upper boundary of Sequence CB3, shown in Figure 3 in reflection time, increases from about 2900 meters near the seaward limit of the upper boundary to about 4500 meters at its landward limit.

Consequently, the Lower Cretaceous sequence at Site 397 has subsided at least 1900 meters since its deposition, whereas the lower Cretaceous shelf edge (represented in our interpretation by the disappearance of the strong top reflector of Sequence CB3) has subsided about 4000 meters. This upslope increase of subsidence is attributed to loading by landward thickening of the overlying Sequence CB2 (Figure 4). The growth faults within Sequence CB3 (Figure 2) and the "slope anticline" (Seibold and Hinz 1974; Hinz et al., 1974) may be the result of the increasing loading.

A 145-meter section of Sequence CB2 was penetrated at Site 369 (Lancelot et al., 1975). It consists of middle Eocene-upper Cretaceous argillaceous nannofossil limestone, marl and chalk, with occasional chert and upper Aptian to Albian dark, silty nannofossil marls. In the drilled section, two hiatuses were observed in the lower Eocene-Paleocene and in Turonianupper Albian. The results of Site 369 indicate that the drilled sediments of Sequence CB2 were deposited on a continental slope above the calcite compensation depth. As mentioned before, the internal seismic configuration of Sequence CB2 is subparallel to divergent whereby the divergent pattern predominates below the downsloping upper boundary of Sequence CB2.

The thickness of Sequence CB2 is shown in Figure 4 as isopachs in reflection time. From about 1500 meters at Site 369, the thickness increases landward to about 3100 meters $(2 \mathrm{sec})$. This increase of thickness is accomplished predominantly by the thickening of individual strata of Sequence CB2, indicating that (1) the deposition during CB2 time was not continuous and the rate of deposition not uniform at the slope off Cape Bojador; and (2) the deposition on the older parts of 


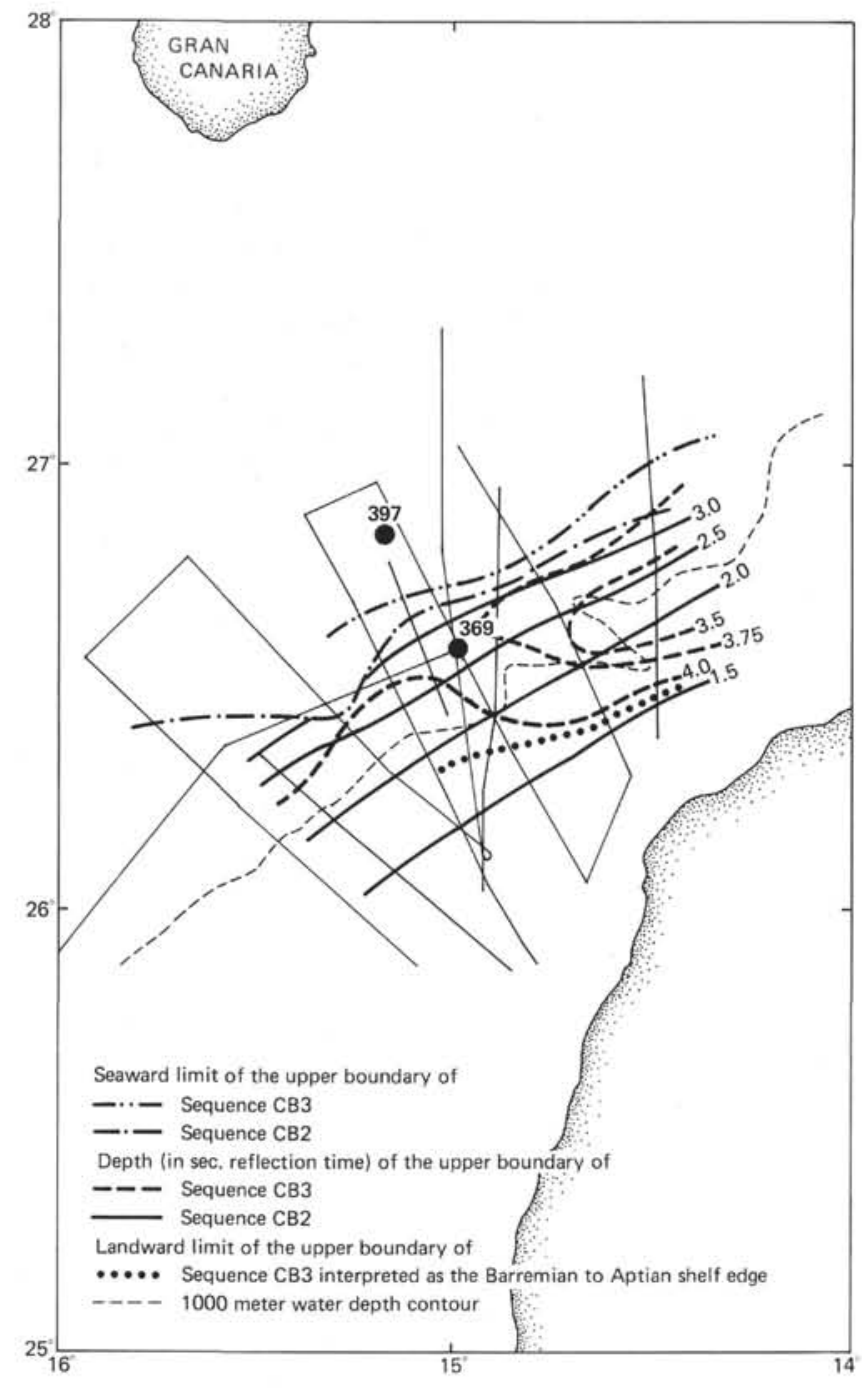

Figure 3. Depth (in sec reflection time) of the upper boundary of Sequence CB3 (Lower Cretaceous sequence) and of the upper boundary of Sequence CB2 (AptianUpper (retaceous sequence).

the slope decreased drastically or even ceased while upbuilding of the slope and shelf continued. Therefore, the upper boundary of Sequence CB2, marked by a distinct unconformity is interpreted as a nondepositional hiatus. The time interval during which nearly no strata were deposited on the top of this unconformity decreases upslope.

At the present seaward limit of the upper boundary of Sequence CB2, an Eocene-Albian (about 70 m.y.B.P.) hiatus is presumed from the seismic data, whereas, lower Eocene-Paleocene (about 17 m.y.B.P.) hiatus was recorded at Site 369.

The lower boundary of Sequence CB2, stratigraphically classified by extrapolation of Site 397 data as Barremian to Aptian (about 115 to 110 m.y.B.P.) lies at Site 369 at a depth of 3.8 seconds, i.e., 3500 meters (Figure 3).

Assuming that the sediments of Sequence CB2 were deposited in nearly the same water depth as the upper Hauterivian sediments at Site 397, e.g., in 100-meters water depth, a subsidence rate of $66 \mathrm{~m} / \mathrm{m}$.y. (1000

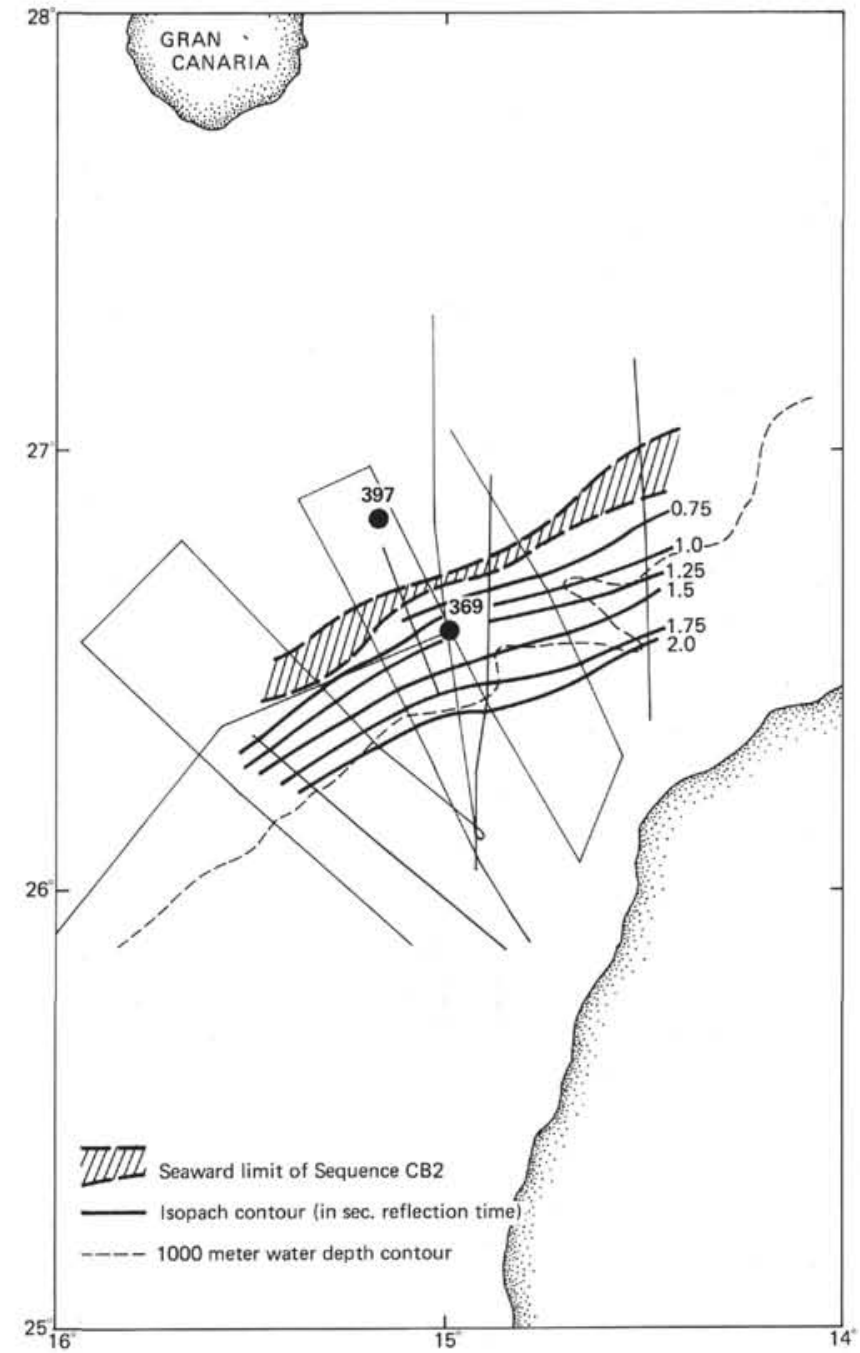

Figure 4. Thickness (in sec reflection time) of Sequence CB2 (Aptian - Upper Cretaceous).

m/15m.y. $=66 \mathrm{~m} / \mathrm{m} . \mathrm{y}$.$) can be derived for the Ap-$ tian-Albian part of Sequence CB2, respectively, and a subsidence rate of $38 \mathrm{~m} / \mathrm{m} . \mathrm{y}$. (2500 m/65 m.y. $=38 \mathrm{~m} /$ m.y.) for the whole Sequence CB2 at Site 369. The subsidence rates are higher than the estimated accumulation rate of $30 \mathrm{~m} / \mathrm{m} . \mathrm{y} .(1500 \mathrm{~m} / 50 \mathrm{~m} . \mathrm{y} .=30$ $\mathrm{m} / \mathrm{m} . \mathrm{y}$.).

The seismic configuration and the difference between the subsidence rate and the accumulation rate implies some combination of relatively high sediment supply and relatively rapid subsidence for the lower part (Aptian) of Sequence CB2, and some combination of decreasing sedimentation and increasing subsidence rates and/or sea level fluctuations during the upper part (Albian-Upper Cretaceous) of Sequence CB2 at the lower slope off Cape Bojador.

Sequence CB1a often consists of a complex set of relatively thin units and/or sequences which are generally characterized by a prograding internal pattern.

At Site 369, Sequence CB1a consists of 125 meters of Quaternary to lower, Miocene nannofossil marl and ooze, and of 210 meters of lower Miocene-middle Eocene marl with minor hiatuses in the upper Pliocene ( 3 
m.y.B.P.) and in the early upper Eocene (7 m.y.B.P.). The thickness of Sequence CB1a increases landward from 335 meters at the location of Site 369 to about 1100 meters at the outer shelf (Figure 5). Below the outer shelf and the upper slope, the seismic configuration of Sequence CBla is characterized by superimposed bottom set strata which thin seaward and apparently terminate by downlap. This configuration and the fact that at Site 369 the rates of accumulation for the Paleogene and Neogene show conspicuous variations (relatively high rates in the middle Eocene, Oligocene, lower Miocene) may imply relatively high sediment supply during individual Tertiary intervals and slow subsidence of the slope and shelf during the past 50 m.y.

Parts of the lower segments of the Tertiary Sequence CBla and most of the lower segments of the

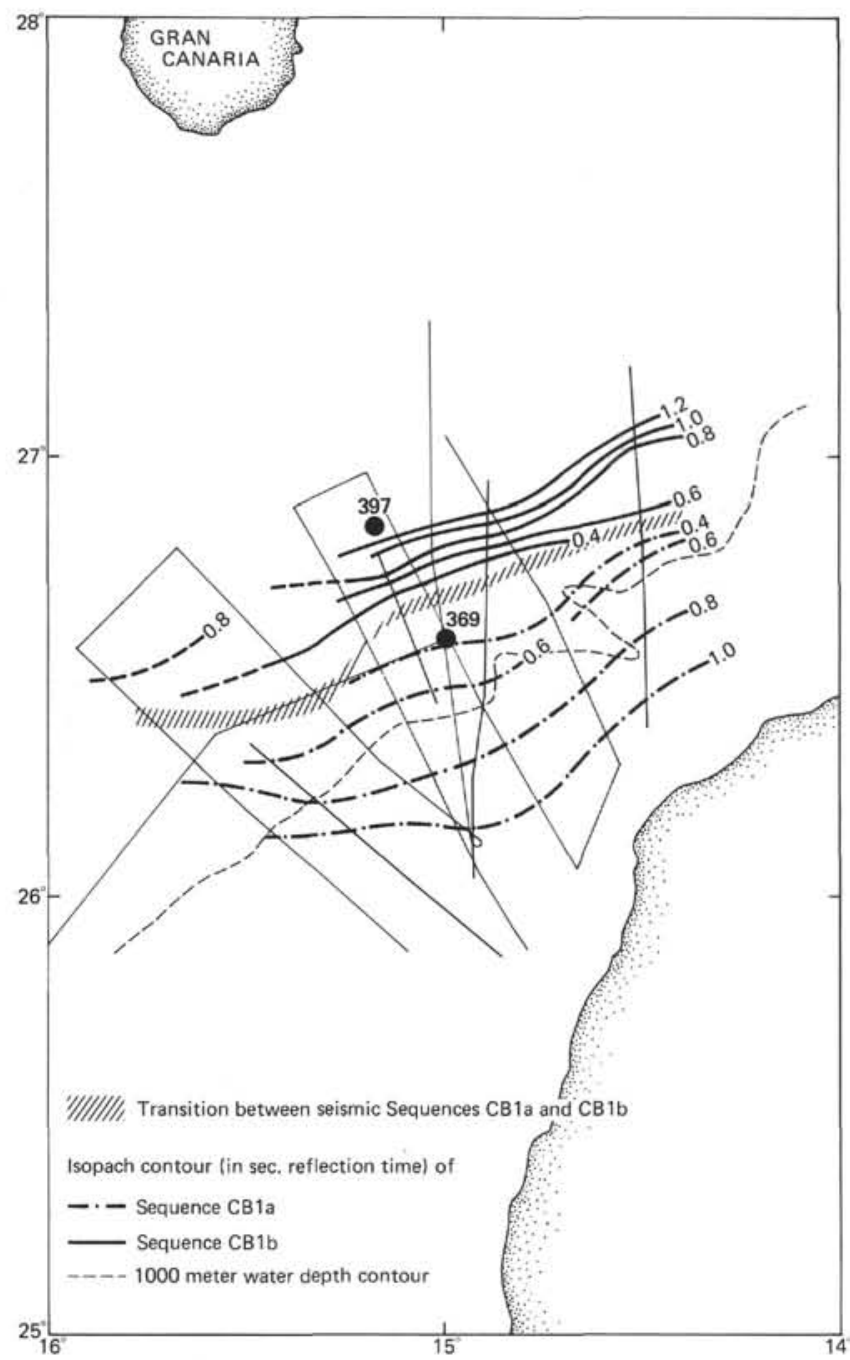

Figure 5. Thickness (in sec reflection time) of Sequences $C B 1 a$ and $C B 1 b$.
Aptian-Upper Cretaceous Sequence CB2, as well as the upper segments of the Lower Cretaceous Sequence CB3, probably originally extended beyond the lower slope and rise but were eroded before deposition of Sequence CB1b.

At Site 397, Sequence CB1b consists of a 1300-meter section of lower to middle Miocene, pebbly mudstone and turbitic sandy mudstone, and middle Miocene to Quaternary marly nannofossil ooze (Site Chapter, this volume).

The thickness (Figure 5) of the Neogene Sequence $\mathrm{CB} 1 \mathrm{~b}$ increases seaward. The lower boundary of Sequence $\mathrm{CBlb}$ (stippled in Figures 1 and 2) is not marked by a strong reflector. It is only identifiable in the seismic records by the termination of systematic reflection patterns. Below the rise, the pattern of both sequences, i.e., of the Neogene Sequence CBlb and the lower Cretaceous Sequence CB3, is parallel to sub-parallel (see right side of Figure 2). Therefore, it is difficult to precisely map the regional distribution of the erosional unconformity underlying the Sequence CBlb.

\section{CONCLUSION}

The results of Site 397 have shown that a regional acousto-stratigraphy should be based on seismic sequences instead of individual reflectors dated from drilled lithologic and stratigraphical events.

\section{ACKNOWLEDGMENTS}

The author wishes to thank N. F. Exon and U. von Rad for reading the manuscript, and $\mathrm{H}$. Schröder and Nath for assistance in preparing the contour and isopach maps. Most of our reflection seismic data were obtained in the frame of Valdivia Cruise VA-10 and Meteor Cruise 25 which were financed by the Federal Ministry of Science and Technology, the German Research Society, and the Bundesanstalt für Geowissenschaften und Rohstoffe.

\section{REFERENCES}

Hinz, K., Seibold, E., and Wissmann, G., 1974. Continental slope anticline and unconformities off West Africa, "Meteor'-Forschungergebnisse, C, no. 17, p. 67-73.

Lancelot, Y., Seibold, E., and Shipboard Party of DSDP Leg 41, 1975. The eastern North Atlantic, Geotimes, v. 20, p. 18-21.

Seibold, E. and Hinz, K., 1974. Continental slope construction and destruction, West Africa. In Burk, C. A. and Drake, C. L. (Ed.), The geology of continental margins. New York, Heidelberg, Berlin, (Springer-Verlag), p. 179196.

Vail, P. R. and Mitchum, R. M. (Eds.), 1977. Seismic stratigraphy and global sea level changes, Am. Assoc. Petrol Geol. Memoir 26 Spec. Volume, v. 1.

von Rad, U., Cepek, P., von Stackelberg, U., Wissmann, G., and Zobel, B., in press. Cretaceous and Tertiary sediments from the Northwest African slope (dredges and cores supplementing DSDP results), Marine Geology. 